\title{
АЛИМЕНТНЫЕ ОБЯЗАТЕЛЬСТВА СОВЕРШЕННОЛЕТНИХ ДЕТЕЙ ПЕРЕД РОДИТЕЛЯМИ В РОССИЙСКОЙ ФЕДЕРАЦИИ И ЗАРУБЕЖНЫХ СТРАНАХ
}

\section{ALIMONY OBLIGATIONS OF ADULT CHILDREN TO THEIR PARENTS IN THE RUSSIAN FEDERATION AND FOREIGN COUNTRIES}

M. Cyrul'nikov

S. Chekulaev

Summary. The responsibility of adult children contain their parents is the Institute of Family Law in almost every country. At the same time, the establishment of alimony obligations is one of the most important institutions of family law. Adult children can be attracted by the court to participate in additional expenses of parents caused by emergency circumstances. The legislature laid on his parents the obligation to share additional costs with adult children, regardless of whether they can work or not. Even in those states in which there is no such commitment at the regulatory level or are poorly regulated - mainly in developing countries - it exists within the framework of religious norms and moral rules (for example, in countries with Muslim law).

Keywords: aliminal obligations, disabled parents, adult children, alimony, family law.
Цырульников Максим Константинович

ФГАОУ ВО «Дальневосточный федеральный

университет»

snkdm4173@gmail.com

чекулаев Сергей Сергеевич

Старший преподаватель, ФГАОУ ВО

«Дальневосточный федеральный университет»

Аннотация. 0бязанность взрослых детей содержать своих родителей является институтом семейного права почти в каждой стране. В то же время установление алиментных обязательств, является одним из самых важнейших институтов семейного права. Взрослые дети могут быть привлечены судом к участию в дополнительных расходах родителей, вызванных чрезвычайными обстоятельствами. Законодательный орган возложил на родителей обязанность разделять дополнительные расходы со взрослыми детьми, независимо от того, могут они работать или нет. Даже в тех государствах, в которых нет такого обязательства на нормативном уровне или которые плохо регулируются — в основном в развивающихся странах — оно существует в рамках религиозных норм и моральных правил (например, в странах с мусульманским правом).

Ключевые слова: алиментные обязательства, нетрудоспособные родители, совершеннолетние дети, алименты, семейное право.

ложения законодательства требуют реформ, основные направления которых описаны далее.

Обязанность детей содержать своих родителей предусмотрена ст. 87 Семейного кодекса РФ. Раздел 1 данной статьи устанавливает обязанность взрослых детей по поддержке и уходу за нуждающимися в помощи родителями-инвалидами. Следует отметить, что данная норма является воспроизведением конституционной нормы, содержащейся в ч. 3 ст. 38 Конституции РФ, которая предусматривает обязанность работающих детей старше 18 лет по уходу за родителями-инвалидами. Отличие формулировок этой статьи заключается в том, что в Конституции РФ применяется слово «забота», а в Семейном кодексе эта «забота» обозначена в виде материальной поддержки (одной из которых является - уход). Также следует отметить, что Конституция Российской Федерации регулирует положение родителей-инвали- 
дов, а Семейный кодекс Российской Федерации предусматривает нуждаемость как дополнительное основание для подачи иска.

Таким образом, для возникновения обязанности по уплате алиментов на содержание родителей законом установлены следующие основания:

- наличие семейных уз между детьми и родителями;

- возраст совершеннолетия детей (т.е. достигших 18 лет) и их трудоспособность;

- инвалидность и нужда родителей.

Согласно ст. 56 ГПК РФ каждая сторона должна представить доказательства обстоятельств, на которые она ссылается в суде. Согласно п. 1 ст. 87 СК РФ при обращении в суд с иском о выплате алиментов на содержание ребенком своих родители, последние должны доказать в суде две причины:

- нетрудоспособность;

- нуждаемость.

Родители считаются инвалидами по достижении пенсионного возраста или по инвалидности (п.п. 3 п. 2 ст. 9 Федерального закона от 17.12.2001 г. № 173-Ф3 «О трудовых пенсиях в Российской Федерации»).

Считается, что родители нуждаются в материальной помощи, когда невозможно обеспечить их достойное существование из-за того, что они не получают пенсии (пособия), или данные выплаты малы, при этом если родители не имеют других источников дохода. Нуждаемость определяется в индивидуальном порядке в судебном органе. При этом сравниваются потребности родителей и необходимые потребности: еда, покупка одежды, предметов домашнего обихода, лечение, прогулка на улице и т.д.

Уголовный кодекс Российской Федерации по ч. 2 ст. 157 предусматривает наступление уголовной ответственности за неоднократную неуплату совершеннолетними трудоспособными детьми средств на содержание нетрудоспособных родителей. По данной теме существуют дискуссии об отсутствии конкретного срока, после которого наступает уголовная ответственность за неуплату алиментов на содержание родителей. Исходя из сравнения с административным законодательством, стоит отметить, что уголовная ответственность сможет наступить в случае, если обязательство по содержанию родителей не исполнялось более трех месяцев.

Также стоит отметить, что дети могут быть освобождены от обязанности содержать своих родителей-инвалидов, если суд установит, что родители:
- уклонились от выполнения родительских обязанностей (ч. 5 ст. 87 СК РФ);

- или были лишены родительских прав (ч. 1 ст. 71 СК PФ).

В большинстве промышленно-развитых стран - особенно в странах романо-германской правовой семьи ответственность детей за содержание своих родителей является достаточно развитым институтом семейного права, который в наше время претерпел наиболее интенсивное развитие.

Кроме того, проблема ответственности взрослых детей за поддержку своих родителей в будущем становится одной из самых актуальных проблем семейного права в развитых странах в условиях ускоренного старения населения в этих странах. В то же время следует отметить, что на развитие института ответственности детей за поддержку своих родителей негативно повлияло развитие так называемого «государства всеобщего благосостояния». Действительно, реализация идей общего благосостояния привела к тому, что обязательство по поддержке нуждающихся было передано с плеч близких (в данном случае детей) государственным органам социального обеспечения. В результате этот институт становится все менее и менее важным в семейном праве в большинстве промышленно-развитых стран.

Например, в контексте законодательной власти Германии: здесь, по сравнению с обязанностями родителей по содержанию несовершеннолетних детей, которым посвящено несколько десятков статей Гражданского уложения (§ § 1626-1699), обязанности детей по содержанию собственных родителей определяется довольно расплывчато, поскольку речь идет не о долге детей, а о долге родственников в целом (§ 1601).

Англосаксонское право регулирует эту проблему менее удовлетворительно. Итак, если первоисточником здесь был Закон о помощи британским бедным 1601 года, который обязывает помогать нуждающимся родственникам, то в современном англосаксонском законодательстве эти вопросы незначительны. В американском гражданском праве, например, эти вопросы регулируются только на уровне штатов различными законами, где они не характеризуются заметной эффективностью и полностью отсутствуют в большинстве из них. Только в исключительных обстоятельствах (например, в соответствии с законодательством Калифорнии) родители могут фактически поручить своим детям обеспечивать их, когда это необходимо.

Согласно исламскому закону, взрослые дети обязаны заботиться о своих родителях, что по сравнению с англосаксонским законодательством свидетельствует о менее 
индивидуалистическом и менее либеральном понимании закона в этой правовой семье. Интересным фактом является то, что, на первый взгляд, согласно Корану, обязанность детей заботиться о своих родителях лежит только на плечах дочери, что связано с особым правовым статусом женщин в мусульманском праве. Однако в Коране есть общие принципы ответственности за своих родителей. Кроме того, в большинстве умеренных мусульманских государств (Алжир, Тунис, Марокко) такое обязательство было секуляризовано путем закрепления в законе и, как в странах с романско-германской и англосаксонской правовой системой, приобрело вторичный характер по сравнению с правовой системой.

Ограниченная важность и второстепенный характер ответственности взрослых детей по уходу за своими родителями очевидны во многих ситуациях, в которых предоставляется такая помощь. Следует отметить, что, хотя условия для оказания такой помощи естественно варьируются от страны к стране, они существуют почти во всех более или менее развитых правовых системах, где дети обязаны заботиться о своих родителях.

Если сравнить условия предоставления алиментов родителям в российском законодательстве с условиями их предоставления в других государствах, можно отметить только одно сходство: предоставление такой поддержки в подавляющем большинстве случаев носит условный характер. Условия, по крайней мере, из-за (материальных) потребностей родителей. В остальном условия, установленные российским законодательством, существенно отличаются от тех, которые мы можем найти в семейном праве других государств.

Например, четкое различие между российским и немецким законодательством в этом вопросе заключается в том, что в немецком законодательстве нет условия для получения выплат родителям от своих детей. В отличие от российского семейного права, в немецком законода- тельстве также отсутствует условие для родительской нетрудоспособности, что является положительным моментом, поскольку родители, даже если они способны работать и фактически работают, могут по-прежнему нуждаться в финансовой поддержке.

В результате было бы логично применить подход, используемый в немецком гражданском праве, в российском праве и не ограничивать возможность содержания детьми своих родителей только в случае их нетрудоспособности. В конце концов, в немецком семейном праве размер алиментов родителям не зависит от трудоспособности детей, что также является серьезным отличием от российского законодательства, которое необходимо адаптировать по этому вопросу, поскольку в этом нет необходимости.

Так же стоит принять во внимание случаи, когда задействованы дети, которые не могут работать (нетрудоспособные), но не имеют материальные возможности помогать своим родителям.

Столь существенные различия в условиях выплаты алиментов родителям обусловлены разным составом субъектов обязанных лиц: в российском законодательстве эти обязанности передаются исключительно детям, а в законодательстве Германии - родственникам в целом (§ 1601).

Из вышесказанного можно сделать вывод, что анализ семейного законодательства показывает, что нормы алиментных обязательств родителей и детей схожи во многих странах мира. Но есть и различия. Следует отметить, что подход семейного права в разных странах к обязанности детей заботиться о собственных родителях далеко не ясен. Что касается нынешнего российского семейного законодательства, то следует сказать, что оно далеко от совершенства и требует ряда нововведений и доработок.

\section{ЛИТЕРАТУРА}

1. Конституция Российской Федерации: текст с изм. и доп. вступ. в силу с 01.07.2020: [принята всенародным голосованием 12.12.1993]. — Москва, 2021.— Доступ из справочно-правовой системы КонсультантПлюс. - Текст: электронный.

2. Семейный кодекс Российской Федерации: текст с изм. и доп. вступ. в силу с 02.03.2021: [принят Государственной Думой 8 декабря 1995 года].—- Москва, 2021. - Доступ из справочно-правовой системы КонсультантПлюс. — Текст: электронный.

3. Гражданский кодекс Российской Федерации: текст с изм. и доп. вступ. в силу с 09.03.2021: [принят Государственной Думой 21 октября 1994 года].—- Москва, 2021.— Доступ из справочно-правовой системы КонсультантПлюс. - Текст: электронный.

4. Гражданский процессуальный кодекс Российской Федерации: текст с изм. и доп. вступ. в силу с 02.03.2021: [принят Государственной Думой 23 октября 2002 года; одобрен Советом федерации 30 октября 2002]. - Москва, 2021. — Доступ из справочно-правовой системы КонсультантПлюс. - Текст: электронный.

5. Уголовный кодекс Российской Федерации: текст с изм. и доп. вступ. в силу с 24.02.2021: [принят Государственной Думой 24 мая 1996 года; одобрен Советом федерации 5 июня 1996]. — Москва, 2021. — Доступ из справочно-правовой системы КонсультантПлюс. — Текст: электронный.

6. 0 трудовых пенсиях в Российской Федерации: текст с изм. и доп. вступ. в силу с 08.12.2020: [принят Государственной Думой 30 ноября 2001 года; одобрен Советом федерации 5 декабря 2001].— Москва, 2021.—- Доступ из справочно-правовой системы КонсультантПлюс.— Текст: электронный. 
7. Грицай Л.А. Идеальные представления и повседневная реальность детско-родительских взаимоотношений в культуре Древней Руси: учеб. пособие / Л.А. Грицай // Педагогика и просвещение.-2013.— № 7.—c. 14 - ISBN978-5-534-02989-5. Текст: непосредственный.

8. Мантулина 0.0. Обязанности совершеннолетних детей по содержанию своих родителей в России и зарубежных странах: учеб. пособие / 0.0. Мантулина // Государство и прав0. - 2014.— № 9.— с. 34 - ISBN978-5-534-10550-6. Текст: непосредственный.

9. Костюченко Е.Ю. Алиментные обязательства родителей и детей по законодательству России и Германии: сравнительно-правовой анализ / Е.Ю. Костюченко. - М.: Изд-во МГЮА, 2011. - c. 111 - ISBN978-601-7566-55-5. Текст: непосредственный.

10. Чекулаев С.С. Проблема сущности понятия «нетрудоспособности» как одного из оснований возникновения алиментных обязательств детей перед родителями по семейному законодательству / С.С. Чекулаев. Д.Е. Тимофеева // Научно-практический электронный журнал Аллея науки.— 2018.— № 1(17).

(c) Цырульников Максим Константинович ( snkdm4173@gmail.com ), Чекулаев Сергей Сергеевич.

Журнал «Современная наука: актуальные проблемы теории и практики»

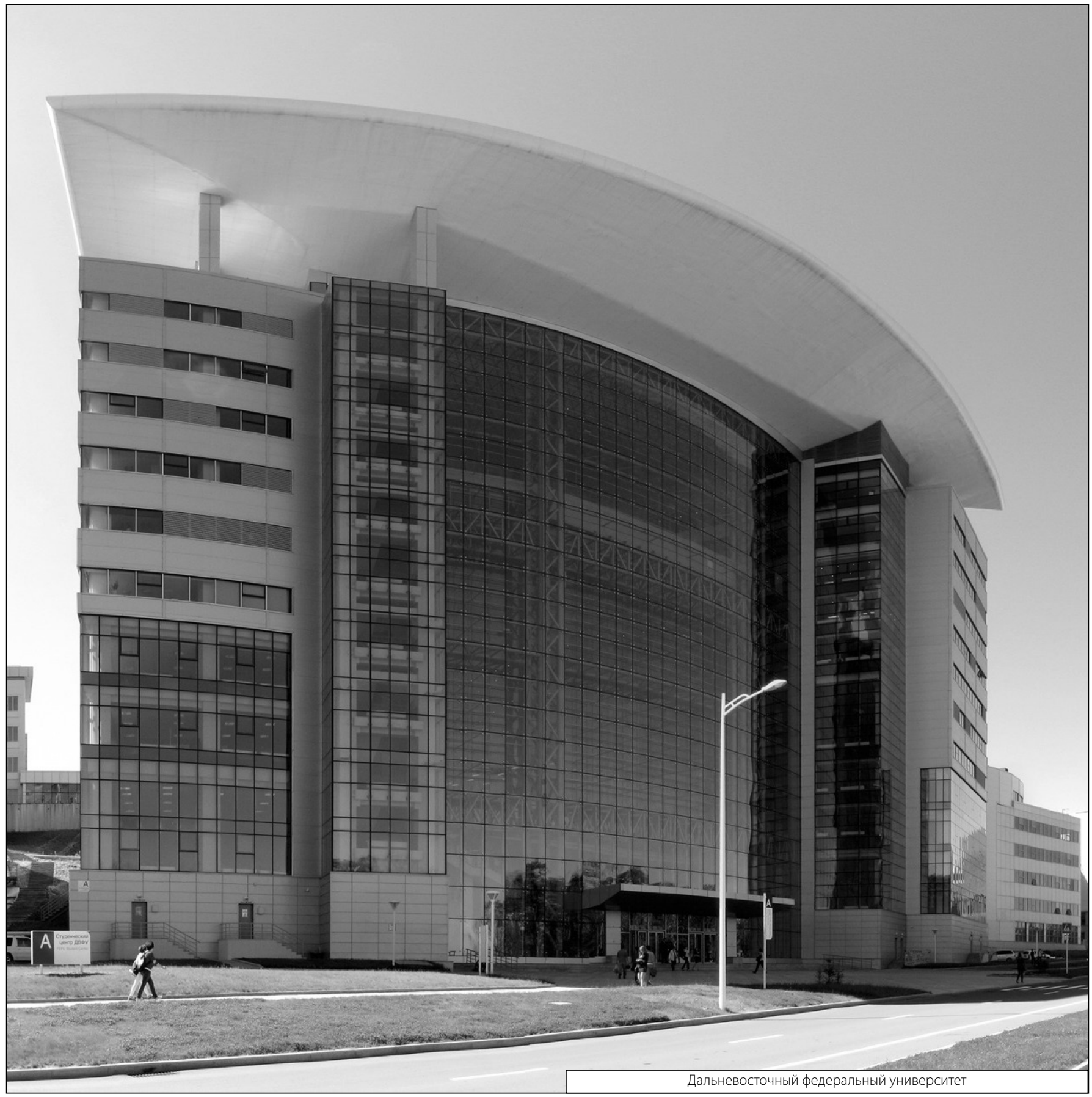

